\title{
Beyond the Pale: Whiteness, Masculinity and Empire in the British Union of Fascists, 1932-1940
}

\author{
Liam J. Liburd \\ Department of History, University of Sheffield \\ ljliburdi@sheffield.ac.uk
}

\begin{abstract}
This article seeks to intervene in the debate over the legacy of the British Empire, using the British Union of Fascists (BUF) as a case-study. It will argue that, during the interwar period, the BUF drew heavily on earlier constructions of racialized imperial masculinity in building their 'new fascist man'. The BUF stand out in the period following the First World War, where hegemonic constructions of British masculinity were altogether more domesticated. At the same time, colonial policymakers were increasingly relying on concessions, rather than force, to outmanoeuvre nationalists out in the Empire. For the BUF, this all smacked of effeminacy and they responded with a 'new man' based on the masculine values of the idealized imperial frontier. By transplanting these values from colony to metropole, they hoped to achieve their fascist rebirth of Britain and its Empire. This article charts the BUF's construction of this imperial 'new fascist man' out the legacy of earlier imperialists, the canon of stories of imperial heroism, and the gendered hierarchies of colonial racism.
\end{abstract}

\section{Keywords}

Britain - fascism - empire - imperialism - masculinity - whiteness Mosley - Chesterton

The debate over the legacy of the British Empire, particularly over the degree to which the domestic British nation was affected by the Empire and over what effect the Empire had on British racial thinking, remains 
contentious. ${ }^{1}$ This article seeks to intervene in this debate, using the British Union of Fascists (BUF) as a case-study. It will argue that, during the interwar period, the BUF drew heavily on earlier constructions of racialized imperial masculinity in building their 'new fascist man'. In an age when the uncompromising imperialists of diehard Conservatism were contained and marginalized within an electorally successful and moderate Conservative Party under the leadership of Stanley Baldwin, Britain's fascist movement was an outlet for unreconstructed imperialism. Rejecting the dominant domesticated constructions of masculinity as well as the more conciliatory direction in imperial policy in interwar British politics, the BUF borrowed from late Victorian and Edwardian imperial discourse. Britain's fascists looked to a masculine ideal based on the conviction that the best of British manhood could be found on Britain's imperial frontiers. Like Kipling and Baden-Powell before them, the BUF found an 'alternative ethic' for British society in the manly code of the frontier existence. ${ }^{2}$ By reviving this imperial 'spirit' in Britain itself, the BUF hoped to combat the enervating decadence they believed was sapping the nation's masculine resolve.

Drawing on studies of fascist masculinity by George Mosse, Julie Gottlieb and Tony Collins, and incorporating insights from the field of imperial history, this article will examine the BUF's construction of an imperially-inflected fascist masculinity. It will do so primarily with reference to the BUF's newspapers and journals, including Blackshirt, Fascist Week, Action, and Fascist Quarterly. In doing so, this article will show how the BUF built upon the legacy of earlier imperialists, used the figure of the imperial frontiersman and imperial heroes as models for a 'new' aristocratic way of life, repurposed the racial hierarchies of colonial masculinity to suit their own ends, and ultimately conceived of fascism as a 'white' fight against the global forces of 'colour'.

For a long time, despite a few (now) old and overlooked pioneering pieces, the relationship between the British radical right and the British Empire went largely unexamined. In the early seventies, Barry Cosmin examined the colonial career of the obscure but prolific anti-Semite, Henry Hamilton Beamish. ${ }^{3}$ Other historians have fleetingly considered the nexus between the radical right

1 Stuart Ward, 'The MacKenziean Moment in Retrospect (or How One Hundred Volumes Bloomed),' in Writing Imperial Histories, ed. Andrew Thompson (Manchester; New York: Manchester University Press, 2013), 29-48.

2 Robert H. MacDonald, Sons of the Empire: The Frontier and the Boy Scout Movement 1890-1918 (Toronto; Buffalo; London: University of Toronto Press, 1993), 5; Robert H. MacDonald, The Language of Empire: Myths and Metaphors of Popular Imperialism, 1880-1918 (Manchester; New York: Manchester University Press, 1994), 159.

3 Barry A. Cosmin, 'Colonial Careers for Marginal Fascists - A Portrait of Henry Hamilton Beamish,' Wiener Library Bulletin 27 (1973-1974): 16-23. 
and imperialism but only recently in a few studies has it come under sustained scholarly analysis. ${ }^{4}$ In these more recent works, the tendency has been to approach imperialism from the purview of fascist studies. ${ }^{5}$ In this article, I hope to shed new light on the imperial nature of British fascism by applying insights from the field of imperial history. In particular, the 'new imperial history', which emphasizes the profound and lingering impact of colonialism on the metropole as well as on the colonized, has a lot to offer, especially where race and gender are concerned. ${ }^{6}$ Discussions of this lingering effect by imperial historians like Catherine Hall, Bill Schwarz, and others have so far neglected the British radical right.

The imperial features of BUF ideology have been noted by gender historians of fascism, such as Tony Collins and Julie Gottlieb. Collins noted that the BUF espoused 'the militaristic masculinity of the late Victorian and Edwardian age', while Gottlieb saw in Mosley's black-shirted recruits 'an unreconstructed masculinity ... associated with a more confident imperial age in Britain's pre-war past. ${ }^{7}$ Beyond these remarks, an in-depth analysis of the relationship between the BUF's ideology and its imperial antecedents is wanting. Additionally, the incorporation of the imperial obsessives on the radical right into the wider debate over Britain's contested imperial past is long overdue.

\section{British Fascism and British Imperialism}

Founded in 1932 by Sir Oswald Mosley, the BUF was not Britain's first fascist movement but was its largest in terms of membership and public profile.

4 Gisela C. Lebzelter, Political Anti-Semitism in England 1918-1939 (London; Basingstoke: Macmillan, 1978), 65; Martin Pugh, 'Britain and its Empire,' in The Oxford Handbook of Fascism, ed. R. J. B. Bosworth (Oxford: Oxford University Press, 2009), 491-492, 499.

5 Kate Imy, 'Fascist Yogis: Martial Bodies and Imperial Impotence,' Journal of British Studies 55 (2016): 320-343; Paul Stocker, 'The Imperial Spirit”: British Fascism and Empire, 1919-1940,' Religion Compass 9, no. 2 (2015): 44-54; Paul Stocker, 'The Postwar British Extreme Right and Empire, 1945-1967,' Religion Compass 9, no. 5 (2015): 162-172; Joe Mulhall, 'From Apathy to Obsession: The reaction of A.K. Chesterton and the British Far Right to Imperial Decline,' Patterns of Prejudice 50, no. 4-5 (2016): 458-477; Evan Smith, 'The pivot of Empire: Australia and the Imperial Fascism of the British Union of Fascists,' History Australia (2017).

6 Stephen Howe, 'Introduction: New imperial histories,' in The New Imperial Histories Reader, ed. Stephen Howe (London; New York: Routledge, 2010), 2.

7 Tony Collins, 'Return to Manhood: The Cult of Masculinity and the British Union of Fascists,' in Superman Supreme: Fascist Body as Political Icon - Global Fascism, ed. J.A. Mangan (London; Portland, or: Frank Cass, 200o), 151; Julie Gottlieb, 'Body Fascism in Britain: Building the Blackshirt in the Interwar Period,' Contemporary European History 20 (2011): 115. 
Before founding the BUF, Mosley had become disillusioned with parliamentary party politics as an MP for the Conservatives and then Labour. In his short-lived New Party, founded in 1931, Mosley's politics began to develop in an increasingly fascist direction. In the BUF, Mosley and his recruits saw themselves as the architects not only of a new and greater Britain but also of new and greater Britons. ${ }^{8}$ He framed his political project in the language of gender; the movement was said to represent 'a microcosm of a national manhood reborn'. ${ }^{9}$ Regarding democracy as effeminate and indecisive, the BuF wanted an authoritarian government to 'replace the legislation of old women by the social sense and the will to serve young men.' ${ }^{10}$

However, in their overt and, moreover, politicized emphasis on an actionoriented manliness, the BUF ran counter to the prevailing mood in Britain. Alison Light has argued that following the First World War there was 'move away from formerly heroic and officially masculine public rhetorics of national identity' to 'an Englishness at once less imperial and more inward-looking, more domestic and more private - and, in terms of pre-war standards, more "feminine"."11 Interwar Britishness was construed less in the image of the imperial adventurer and more in terms of "the little man", the suburban husband pottering in his herbaceous borders. ${ }^{12}$

This wider cultural mood was embodied in politics by Stanley Baldwin, Conservative Party leader from 1923 to 1937 and Prime Minister at various times during the 1920 and 1930s. Baldwin's moderate Conservatism 'offered a more domestic and feminised image', accepted democracy, and was reticent about power and aggression..$^{13}$ The BUF fulminated against this understated ideal of manliness within Westminster and beyond. They mockingly referred to Baldwin as 'Mrs Baldwin', denounced other National Government politicians as 'old

8 George L. Mosse, The Image of Man: The Creation of Modern Masculinity (New York; Oxford: Oxford University Press, 1996); Julie Gottlieb, 'Britain's New Fascist Men: The Aestheticization of Brutality in British Fascist Propaganda', in The Culture of the Fascism: Visions of the Far Right in Britain, ed. Julie Gottlieb and Thomas Linehan (London; New York: I.B. Tauris, 2004), 83-99.

$9 \quad$ Oswald Mosley, The Greater Britain, $2^{\text {nd }}$ ed. (London: BUf, 1934), 53.

$10 \quad$ Mosley, The Greater Britain, 53.

11 Alison Light, Forever England: Femininity, Literature and Conservatism between the Wars (London; New York: Routledge, 1991), 8.

12 Light, Forever England, 9.

13 Martin Pugh, 'Hurrah for the Blackshirts!': Fascists and Fascism in Britain between the Wars (London: Jonathan Cape, 2005), 83; Richard Whiting, 'The Empire and British Politics,' in Britain's Experience of Empire in the Twentieth Century, ed. Andrew Thompson (Oxford: Oxford University Press, 2012), 170. 
women', and complained of the 'oppressive feminine vapours' suffocating the nation. $^{.4}$

This moderation of politics at home extended to colonial policy as well. Facing growing nationalist stirrings across the Empire, imperial policymakers looked to the eventual goal of self-government, within an imperial or Commonwealth framework, as a means of securing imperial ties. ${ }^{15}$ Over the course of the 1920 and early 1930s, this new approach saw formal independence (with caveats) for Egypt in 1922, and what was essentially full recognition as states in their own right for Britain's Dominions with the Balfour Declaration of 1926 and the 1931 Statute of Westminster. This even extended, though always rather disingenuously, to Britain's non-white colonies. In 1931, Baldwin endorsed the Irwin Declaration that made further promises of eventual dominion status for India.

Barbara Bush has portrayed this as a 'feminization of Empire.'16 In this gradual reconceptualization from 'Empire' to 'Commonwealth', she sees a significant shift in imperial discourse. It is important not to overstate this, however; the British Empire had not suddenly transformed into a benign and motherly institution. This change had more to do with outmanoeuvring nationalists than it did with humanitarianism. Nonetheless, it was perceived by those on the radical right as outright treachery, a betrayal frequently condemned in the language of gender. For the BUF and 'diehard' elements within the Conservative Party, it represented the enervating counterpart to sapping decadence at home.

An interesting feature of interwar British politics was the way in which the Conservative Party, under Baldwin's leadership, for the most part contained and defanged the dissident diehards within its ranks. ${ }^{17}$ Very few Tories strayed, constrained by Baldwin's vote-winning constitutional Conservatism and subsumed within a party committed to a strategy of imperial preservation by

\footnotetext{
14 A.K. Chesterton, 'Regiment of Old Women Routed,' Action, 21 (July 9, 1936), 9.

15 John Darwin, 'Imperialism in Decline? Tendencies in British Imperial Policy between the Wars,' The Historical Journal 23, no. 3 (1980): 657-679; Peter Marshall, '1918 to the 196os: Keeping Afloat,' in The Cambridge Illustrated History of the British Empire, ed. Peter Marshall (Cambridge: Cambridge University Press, 1996), 81-97; Whiting, 'Empire and British Politics', 163-164.

16 Barbara Bush, 'Gender and Empire: The Twentieth Century,' in Gender and Empire, ed. Philippa Levine, (Oxford: Oxford University Press, 2004), 80.

17 Stephen Ball, Portrait of a Party: The Conservative Party in Britain, 1918-1945 (Oxford: Oxford University Press, 2013), 79-81, 342-348; N. C. Fleming, 'Diehard Conservatism, Mass Democracy, and Indian Constitutional Reform, c.1918-35, Parliamentary History 32, no. 2 (2013): 343-344.
} 
way of the carrot rather than the stick. The BUF was one of the few entities in Britain offering unreconstructed imperial masculinity as a political programme. In popular culture, heroic high imperialism persisted; as George Orwell noted in 1940, in boys' weeklies it was mentally still 1910 and 'at the outposts of Empire the monocled Englishmen are holding the niggers at bay.18 But in the world of politics, the rough-and-ready Kiplingesque imperialism of the late Victorian and Edwardian period had its second life in interwar British fascism.

\section{The Significance of the Frontier in British Imperial History}

In opposition to this 'effeminate' tendency in British society and imperial policy, the BUF sought an alternative ethic for Britain in a masculinity associated with the imperial frontier. As Catherine Hall and Bill Schwarz have demonstrated, the idea that the best of British manhood, and the means to revive it back in the metropole, could be found out on Britain's imperial hinterlands stems back to the mid-nineteenth century. Though they overlooked interwar British fascism in their analysis, Hall and Schwarz have charted the long history of this imperial ideal of white masculinity. They each traced it back from Enoch Powell and Ian Smith, through Joseph Chamberlain and Lord Alfred Milner, and back to the writings of Thomas Carlyle and the imperialist travelogues of Charles Dilke, J. A. Froude and J. R. Seeley.19

The omission of interwar British fascism from the history of the idealized frontier manliness is even more intriguing when one considers that historians have long been pointing out the affinities between British fascism and social imperialism. Edwardian social imperialists like Joseph Chamberlain, a Liberal Unionist MP and Colonial Secretary (1895-1903) and Lord Milner, who had worked in various imperial administrative posts, sought to unite Britain and the colonies to mutual economic advantage and in order to foster a regenerative spirit of Empire in the metropole. ${ }^{20}$ The resemblances between Mosley's imperial vision as set out in The Greater Britain and the social-imperialist designs

18 G. Orwell, 'Boys' Weeklies,' [1940] in The Collected Essays, Journalism and Letters of George Orwell, Volume 1: An Age Like This, 1920-1940, ed. Sonia Orwell and Ian Argus (Harmondsworth: Penguin, 1975), 518. See also, Kelly Boyd, 'Exemplars and Ingrates: Imperialism and the Boys' Story, 1880-1930,' Historical Research 67, no. 163 (1994): 143-155.

19 Catherine Hall, White, Male and Middle Class: Explorations in Feminism and History (Cambridge: Polity, 2005), 286; Bill Schwarz, The White Man's World (Oxford: Oxford University Press, 2013), 71-102.

20 Barbara Farr, The Development and Impact of Right-Wing Politics in Britain, 1903-1932 (London; New York: Garland, 1987), iv; Schwarz, The White Man's World, 175. 
of Chamberlain and his supporters prompted Bernard Semmel to proclaim Mosley 'the intellectual heir of the most extreme wing of Chamberlainism, of protectionist social-imperialism. ${ }^{21}$ Both Thomas Linehan and Alan Sykes have placed Chamberlainite social imperialism and Mosleyite fascism within the longer history of an anti-liberal, authoritarian, nationalist, and imperialist British political tendency. ${ }^{22}$ Throughout his political career, Mosley described his own political outlook in distinctly Milnerite terms as 'imperial socialism' or 'socialistic imperialism. ${ }^{23}$

Alongside this, the BUF were clearly influenced by an imperially-infused popular culture. A regular imperialist trope in popular culture during the late Victorian and Edwardian years was the 'frontier myth', another rendering of the conviction that the frontier lifestyle represented the apotheosis of heroic manliness. ${ }^{24}$ This myth was articulated through stories of imperial heroism which proliferated between $185^{\circ}$ and 1914. Through transformative encounters with the 'primeval region' of the frontier, places like North-West Canada or the thick jungles of Africa, the protagonists of these tales were elevated to the mantle of heroism. ${ }^{25}$ According to John MacKenzie, such stories became part of popular culture, in books, in magazines, in theatres, in music-halls, and in the classroom. Their heroes were not remote superhuman figures but 'moral exemplars.' ${ }^{26}$ Dramatizations of their deeds conveyed 'models for behaviour applicable to everyday life, "How To" guides for confronting danger, responding to set-backs, interacting not only with friends, but also with enemies. ${ }^{27}$

21 Bernard Semmel, Imperialism and Social Reform: English Social-Imperial Thought 1895-1914 (London: George Allen \& Unwin, 1960), 248. Oswald Mosley, The Greater Britain (London: B.U.F. Publications, 1932). The title of Mosley's book made use of a term popularised by Charles Dilke's 1868 book, Greater Britain. For the wider context of 'Greater Britain', see Duncan Bell, The Idea of Greater Britain: Empire and the Future of World Order, 1860-1900 (Princeton; Oxford: Princeton University Press, 2007).

22 Alan Sykes, The Radical Right in Britain: Social Imperialism to the BNP (Basingstoke; New York: Palgrave Macmillan, 2005). See also, chapter 1 in Thomas Linehan, British Fascism 1918-1939: Parties, Ideology and Culture (Manchester; New York: Manchester University Press, 2000).

23 Lord Alfred Milner, The Nation and the Empire (London: Constable, 1913), 161; Oswald Mosley, My Life (London: Nelson, 1968), 168; “'Socialistic Imperialism"', Action, 158 (March 4, 1939), 7 .

24 MacDonald, Sons of the Empire, 5 .

25 John MacKenzie, 'Heroic myths of Empire,' in Popular Imperialism and the Military, 18501950, ed. John MacKenzie (Manchester: Manchester University Press, 1992), 114.

26 MacKenzie, 'Heroic myths of Empire,' 112.

27 Max Jones et al., 'Decolonising Imperial Heroes: Britain and France,' The Journal of Imperial and Commonwealth History 42, no. 5 (2014): 798. 
The BUF possessed their own 'pantheon of heroes' stocked full of exemplary figures hailed for their 'perceived manliness'. ${ }^{28}$ Here, the BUF were not inventing new heroes but rather plundering an imperialist mythology that long predated it, repurposing historical figures as Great British proto-fascists. Their fascist pantheon included, but was not limited to, Sir Francis Drake, Sir Walter Raleigh, Captain James Cook, Major-General James Wolfe, Robert Clive (better known as 'Clive of India'), Horatio Herbert Kitchener, and the first GovernorGeneral of India, Warren Hastings.

The BUF were profoundly influenced by one of the most famous celebrators of Empire and imperial heroes in English letters, Rudyard Kipling. The BUF's Director of Publicity and Propaganda, A.K. Chesterton, penned Kipling's obituary in Action, dubbing him 'the poet of Empire' and declaring that 'Kipling himself' would have been a fascist if he had 'been born twenty or thirty years later'.29 Kipling was never a fascist and insofar as he was involved in British politics during the interwar period, he remained within the fold of diehard Conservatism serving as one of the vice-presidents of the Indian Empire Society and the India Defence League. ${ }^{30}$ Despite this, through his writing he contributed greatly to the ideal of racialized imperial masculinity that was very appealing to Britain's fascists. Kipling's 'frontier verses', a series of poems mostly published during the 189os that deal with 'the men who come, suffer, and find their manhood on the boundaries of Empire', are illustrative of this contribution. ${ }^{31}$ The BUF drew inspiration from Kipling's frontiersmen, 'The Gentleman Rovers abroad', who were courageously risking life and limb in pioneering, 'breaking the road for the rest. ${ }^{32}$

They were also encouraged by Kipling's condemnation of 'London decadence' against which he set 'frontier virility' ${ }^{33}$ Kipling's poetry was a call to arms to those back in Britain to take up the task of maintaining the Empire. In poems like 'The Native Born', he attacked British indifference to Empire while

28 Collins, 'Return to Manhood,' 153.

29 A.K. Chesterton, 'The Best of His Spirit Still Shall Live,' Blackshirt, 144 (January 24, 1936), 3. Chesterton's imperialism was the constant of his political career; after the Second World War, he founded and led the über-imperialist League of Empire Loyalists (1954-1967).

'The India Defence League,' The Indian Empire Review 2, no. 7 (July, 1933), 5-7; The Indian Empire Review 3, no. 11 (November, 1934). Kipling was also, privately, a believer in the authority of The Protocols of the Elders of Zion. See Bryan Cheyette, Constructions of 'the Jew' in English Literature and Society: Racial Representations, 1875-1945 (Cambridge: Cambridge University Press, 1995), 88.

31 MacDonald, Language of Empire, 157, 158.

32 Rudyard Kipling, 'The Lost Legion,' in The Seven Seas (London: Methuen, 1897), 96, 98.

33 MacDonald, Language of Empire, 160. 
praising 'five-meal, meat-fed men' among the 'native-born' settlers in the colonies. ${ }^{34}$ In these and other odes to the 'White Man' throughout the Empire and Kipling's attempts to rekindle a virile imperial spirit in the metropole, the BUF found an example to emulate and, moreover, an example with a good deal of fascist potential. For Chesterton, the 'Kipling mood and ... temperament' were concerned with might not rights. ${ }^{35}$ Kipling's writings, he went on, were 'for those who aspired to be men, who aspired to deal with their fellows like men, and like men to work out their lives and always speak out the truth within themselves. ${ }^{36}$ Chesterton lamented the passing of Kipling and of the confident, imperialist era he chronicled. He pledged that the spirit of both 'shall live again, and still more greatly, in the future of British Fascism. ${ }^{37}$

Along with Kipling, the BUF had unreserved praise for Robert Baden-Powell who, decades before the BUF, had attempted to turn the 'frontier ethic' into a practical code of life. In his 1908 book Scouting for Boys, the manifesto of his new Boy Scout movement, Baden-Powell sought to teach young boys in the ways of 'real men' such as '[ $\mathrm{t}]$ he "trappers" of North America, hunters of Central Africa, the British pioneers, explorers, and missionaries all over Asia and the wild parts of the world, the bushmen and drovers of Australia, [and] the constabulary of North-West Canada and of South Africa. ${ }^{38}$

A veteran of the Boer War, Baden-Powell's Scout philosophy was motivated by the fear 'that young Englishmen would prove themselves weaklings ... that they would fail "the supreme test of manhood" in battle. ${ }^{39}$ His proposed solution was to 'train a large number of boys' to follow in the footsteps of imperial heroes like Raleigh, Drake, Cook, and Clive 'as regards character and manliness. ${ }^{40}$ Elleke Boehmer identifies a 'hierarchical vision of imperial bonding between strong men' in Scouting for Boys, a vision she argues is derived 'from imperialist thinkers like Rudyard Kipling and Cecil John Rhodes (who in turn had it from Charles Dilke and J. R. Seeley). ${ }^{\text {41 }}$

34 Rudyard Kipling, 'The Native Born,' in The Seven Seas (London: Methuen, 1897), 49-54.

35 Chesterton, 'The Best of His Spirit,' 3.

36 Ibid.

37 Ibid.

38 Robert Baden-Powell, Scouting for Boys: A Handbook for Instruction in Good Citizenship (London: Horace Cox, 1908), 12.

39 MacDonald, Sons of the Empire, 3.

$40 \quad$ Baden-Powell, Scouting for Boys, 341.

41 Elleke Boehmer, 'The Text in the World, the World through the Text: Robert Baden Powell's “Scouting for Boys", in Ten Books That Shaped the British Empire: Creating an Imperial Commons, ed. Antoinette Burton and Isabel Hofmeyr (Durham; London: Duke University Press, 2014), 134. 
While the militaristic imperial image of the Scout movement was toned down after the First World War and replaced with 'an image of League of Nations internationalism and later world Commonwealth brotherhood', it was this earlier incarnation that captured the imagination of Britain's fascists. ${ }^{42}$ Writing in Action, Roger Corbet, himself involved with the Scout movement, afforded Baden-Powell the dubious honour of being 'probably the first National Socialist England had. ${ }^{43}$ Both Baden-Powell and Mosley, he wrote, were motivated by 'similar ideas', the difference being that Mosley took Baden-Powell's ideas one step further 'and applied his creed to politics' 44 The quest of the Scouts to inculcate the masculine values of the frontier in Britain's youth was portrayed as the prelude to Mosley's fascist odyssey to imperialize the nation along similar lines. Mosley, Corbet believed, was going to lead the nation to a Greater Britain with the high ideals of Scouting. ${ }^{\prime 5}$ Much like the Scouts, the figure of the frontiersman provided the BUF with a model for a new type of citizen, only in their case this meant a new fascist man.

\section{The New Fascist Frontiersman}

The new fascist men who were to carry out the rebirth of Britain and her Empire saw themselves as taking the torch from earlier imperial pioneers. They were going to remake Britain just as, according to heroic tales, great men had made the Empire. As one fascist, writing in 1934, plainly put it, 'It is the direct object of Fascism to revive the pioneering spirit upon which the magnitude of the British Empire is founded.46 Olive Hawks, an enthusiastic activist in the BUF's Women's Section, proclaimed that with the rise of the 'New Man' of British fascism 'Our Drakes, our Clives and Cromwells have risen again in the islands of their birth. ${ }^{47}$ Their struggle 'to maintain and to re-unify' the Empire, would require 'the questing, fearless spirit' of Britain's imperial pioneers, the spirit that also formed 'the true essence of Fascism.' ${ }^{48}$

\footnotetext{
42 John Springhall, Youth, Empire and Society (London: Croom Helm, 1977), 63.

43 Roger Corbet, 'Red Hands on Boy Scouts,' Action, 93 (November 25, 1937), 9.

44 Corbet, 'Red Hands,' 9.

45 Ibid.

46 James Rudd, 'Fascism's Mission to British Youth,' Blackshirt, 75 (September 28, 1934), 6.

47 Olive Hawks, 'Revolution is a National Characteristic,' Blackshirt, 87 (December 21, 1934), 6.

48 Hawks, 'Revolution,' 6.
} 
The BUF's resident philosopher, Alexander Raven Thomson, wrote of fascism as the rule of 'The true aristocrat, the born leader of men'49 Like Hawks' 'New men', Raven Thomson's 'true aristocrats' were modelled on men like Drake and Raleigh; men who, in his words, 'suffered hardship and risked danger to lay the foundations of the British Empire. ${ }^{50}$ These 'true aristocrats' were to lay the foundations of British fascism in a political revolution akin to an great act of Empire-building; just as Britain had colonized the world, the new fascist frontiersmen of the BUF were going to 'colonise Britain'.51

BUF members cast their leader as the latest and greatest in the long line of Empire-building 'great men'. As the newest addition to their fascist pantheon of imperial heroes, they believed that Mosley would 'outshadow all the great Empire builders of the past'. ${ }^{2}$ In the hopes of BUF recruits, Mosley was going to go down in history as the man who consolidated the British Empire, finishing off the work started by earlier Empire builders. Mosley was imagined as a man in the heroic tradition, representing a masculinity whose natural habitat was on 'the battlefield, or the backwoods, or with his hunters in the jungle'.53 They conceived of his fascist mission as similar to the imperial mission of nineteenth-century British heroes. His fight against British fascism's enemies within, 'against the serpent of corruption, stagnancy, decadence, and Jewry', was compared to the fight led by Admiral Nelson against an external foreign foe in the previous century. ${ }^{54}$

The grandiosity of the BUF's imperial policy reflected this intense faith in the willpower of 'great men'. The decline of the Lancashire cotton industry was an obsession for Mosley. For the BUF, it was an issue that linked imperial politics to the bread-and-butter realities of British working-class life. Mosley took aim at the threats to the Lancashire cotton industry such as the use of cheap labour in Indian cotton mills, the imposition of high Indian tariffs on British exports, and the danger that Britain would lose its Indian market for cotton to Japan. ${ }^{55} \mathrm{He}$ proposed a raft of measures a fascist government would take to deal with this including forcing India to lower tariffs, requiring Indian cotton mill owners to pay higher wages, excluding foreign textile manufacturers from

49 Alexander Raven Thomson, 'Aristocracy of Worth', Fascist Week, 13 (February 2-8, 1934), 4.

$50 \quad$ Raven Thomson, 'Aristocracy,' 4.

51 Roger Gould, 'Re-Colonisation of Britain,' Fascist Week, 11 (January 19-25, 1934), 1.

52 W. J. Leaper, 'Leader's Inspired Speech,' Blackshirt, 53 (April 27-May 3, 1934), 1.

53 G. De Burgh Wilmot, 'Blackshirts are Warriors of the New Age,' Blackshirt, 59 (June 8, 1934), 6.

54 I.F.P., “England Expects", Action, 26 (August 13, 1936), 8.

55 Martin Pugh, 'Lancashire, Cotton and Indian Reform: Conservative Controversies in the 1930s,' Twentieth Century British History 15, no. 2 (2004): 144. 
trading with the colonies, and encouraging Japan to trade directly with Lancashire. ${ }^{56}$ Added to this, a fascist Britain would, according to Mosley, encourage the development of agriculture rather than industry in India and would suppress Indian nationalism. Mosley also threatened that, as a last resort, he was not above 'closing down every single cotton mill in India., ${ }^{57}$

Martin Pugh has called Mosley's plans to put down India's increasingly bold Nationalist movement and its burgeoning textile industry in one fell swoop 'highly unrealistic.'58 Mosley's biographer, Robert Skidelsky described the BUF's policy as one of 'holding India down by force. ${ }^{59}$ Mosley's own understanding of his plans was quite different and illustrates the way in which British fascism aspired to conduct itself in the spirit of imperial heroism. The issue of India's future was discussed by Mosley not in terms of imperial realpolitik but with reference to a pivotal moment in British imperial history. 'We held India during the Mutiny', he proclaimed in a 1935 speech, referring to the 1857 Indian Mutiny. ${ }^{60}$ For Mosley, maintaining this hold would be a test of British manhood; they faced 'one-tenth of the problem which faced our ancestors' and failure to hold India would mean 'we would be one hundredth the men they were.' 61

\section{'Empire Builders' versus ‘Old Women’}

The men who built the Empire functioned not only as an example to be emulated but also a yardstick with which to measure, and then to beat, their enemies. Writing in Fascist Week under the pseudonym 'Lucifer', William Joyce contrasted the 'tough men' of Empire with the middle-class, leftish intellectuals he called 'soft, white Bloomsburys'. ${ }^{62}$ According to Joyce, fascists intended to 'revere and admire and ... emulate' the Empire builders, men like Captain Cook and Major-General Wolfe. He cast left-wing intellectuals as sexual and racial abnormalities worshipping at the altar of 'Marx and Engels', and other

\footnotetext{
56 Oswald Mosley, Fascism: 100 Questions Asked and Answered (London: B.U.F. Publications, 1936), 61; Pugh, 'Lancashire, Cotton and Indian Reform,' 147-148.

57 Mosley, Fascism, 62.

$5^{8}$ Pugh, 'Lancashire, Cotton and Indian Reform,' 148.

59 Robert Skidelsky, Oswald Mosley (London, 1990), 307.

6o Theo Lang, 'The Albert Hall Rally, Blackshirt, 101 (March 29, 1935), 2.

61 Lang, 'Albert Hall Rally,' 2.

62 Richard Thurlow, Fascism in Britain: From Oswald Mosley's Blackshirts to the National Front (London; New York: I. B. Tauris, 1998), 128; 'Lucifer', 'Pink Dreams in a Yellow Jacket,' Fascist Week, 2 (November 17-23, 1933), 7.
} 
foreign radicals. ${ }^{63}$ British fascists belonged to a far more heroic tradition, argued Joyce, as the latest incarnation of the 'men ... who built Britain and the British Empire'.64 Fascists, he maintained, intended 'to live in [the] spirit' of the 'Empire Builders' and 'maintain their work' ${ }^{65}$

Against the virile, pioneering manhood of Empire, the BUF also unfavourably compared Britain's elder statesmen. M. Hobson-Cooke, writing in Action, lamented that 'the England of Drake, of Wolfe, of Clive, of Nelson' was being replaced by a nation of ' $[\mathrm{t}]$ imorous and podgy stomached' democratic men. ${ }^{66}$ Hobson-Cooke hoped that fascism would 're-hew' the British people into a figure resembling the 'daring; self-sacrificing; athletic' Empire-building Englishmen. ${ }^{67}$ Similarly, Mosley urged that modern statesmen should live like athletes and compared Nelson and Drake with the 'youthful Foreign Secretary' who can be incapacitated 'for six weeks' by '[a] rough journey in an aeroplane from Cologne to London'.68 There were no signs of mental fatigue or nervous breakdown, he maintained, when Drake faced the Armada or Nelson fought the Battle of the Nile. ${ }^{69}$ Next to imperial heroes, the politician lived an 'ignoble' and unmanly existence, a life characterised by an abundance of talk and a lack of action. ${ }^{70}$

For A.K. Chesterton, the creation and maintenance of the Empire was the result of 'the zeal, hard work, and heroism of our fighting men, our pioneers, our colonists, our colonial administrators and our handfuls of colonial police. ${ }^{71}$ Moreover, they had accomplished this feat 'in spite of the politicians. ${ }^{72}$ Politicians at home were seen as an active impediment to Empire-building; a sentiment bluntly conveyed in his remark that 'Men make Empires: politicians degrade and lose them. ${ }^{73}$ The democratic politician stood in for the system he represented, seen by fascists as ineffective, weak and prone to collapse. He was the very opposite of the imperial hero, who was portrayed as the masculine antecedent to fascism's new man. Much like the BUF's new fascist man, wrote

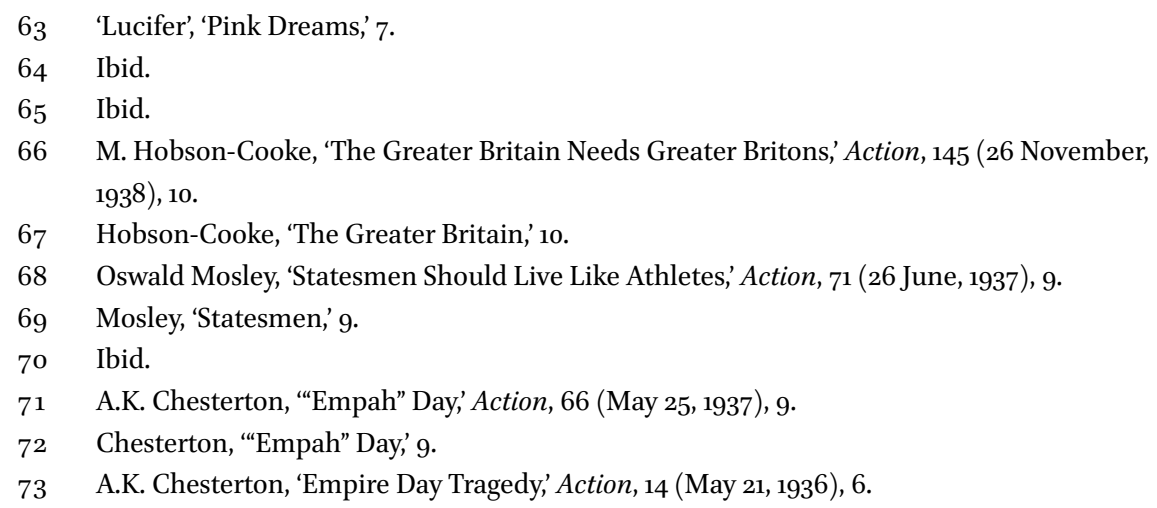


Joyce, 'Drake and Raleigh and Hawkins ... would not have entered the House of Commons, except to spit in it. ${ }^{\prime 7}$

This distinction, perpetually drawn between the imperial man on the one hand and the democratic politician on the other, speaks to the depth of British fascism's engagement with imperialism. According to Roger Griffin, fascism seeks to engineer 'a new sort of "man" in an alternative socio-political and cultural modernity to liberal capitalism. ${ }^{75}$ The BUF found their new man as well as their 'alternative modernity' in imperialism. The legacy of the British Empire stood out for fascists as a glowing example of what Britain could do in spite of democracy. Imperialism appeared to them as men acting, not talking or debating or otherwise engaging in democracy but exerting their will upon the world and the people in it. The BUF revelled in the stark difference between imperialism and democracy; 'the death of democracy', wrote Joyce, 'is the life of Imperialism: ${ }^{76}$ In their conception of the aristocratic imperial hero, they saw an individual who was capable of transforming the world around him through sheer will. Standing as a rejection of democracy as a system and a philosophy, imperialism represented 'the dynamic forces of heroic man in his struggle with crude and primitive nature. 77

In a double-page spread in the BUF's Action newspaper on 'The Men Who Built the British Empire', E. D. Hart distilled the lives of Britain's 'Empire Builders' down into two political lessons. One was that where the Empire flourished it was not down to a parliament full of elected politicians but to an 'appointed ... suitable person' who was then 'given ... a free hand. ${ }^{78}$ And the other, was that imperial blunders had resulted from 'unintelligent interference' on the part of party politicians. ${ }^{79}$ The BUF found in their fascist mythology of the British Empire an object lesson in the superior qualities of fascist leadership when compared to its democratic counterpart. As Joyce put it, fascism was out to revive '[ $t$ ] he era of Imperial leadership' in which 'Politicians are no longer to be tolerated' 80

\footnotetext{
$74 \quad$ 'Lucifer', 'Pink Dreams', 7.

75 Roger Griffin, 'Studying Fascism in a Postfascist Age: From New Consensus to New Wave?' Fascism: Journal of Comparative Fascist Studies 1 (2012): 1, accessed July 26, 2018, doi: 10.1163/221162512X623601.

76 William Joyce, 'The Philosophy of Empire,' Fascist Week, 27 (May 11-17, 1934), 1.

77 Joyce, 'Philosophy of Empire,' 1.

78 E. D. Hart, 'Men Who Built the British Empire: A Survey of the Great Colonists', Action, 65 (May 15, 1937), 9.

79 Hart, 'Men Who Built the British Empire,' 9.

$80 \quad$ Joyce, 'Philosophy of Empire,' 1.
} 


\section{The BUF and Imperial Racism}

Much like earlier incarnations of imperial manliness, the BUF's imperial masculinity defined itself against non-white men. As Bill Schwarz has noted, 'the white man could only be a white man in relation to his others: his whiteness and his masculinity acquired meaning only in relation to those who had no claims, or lesser claims, to whiteness or to masculinity'. ${ }^{81}$ In the process of fashioning new men based on old imperial ideals, the BUF worshipped a whiteness sharpened by colonial encounter. This is unsurprising when one considers that, as W. F. Mandle demonstrated, a significant number of their members had had such encounters themselves. Among his sample of 103 members of 'the BUF elite', consisting of party workers and election candidates, he found that around seventy had 'travelled, served or worked overseas'. ${ }^{82}$

Africa, India, and the Far and Middle East featured prominently among the locations travelled to. Mandle noted the presence of four ex-Indian Army officers and 'at least sixteen' with 'some experience' of Africa including Robert Gordon-Canning, who fought in Morocco, and A.K. Chesterton, who was born in South Africa and worked there briefly after the First World War as a prospector and then as a journalist. ${ }^{83}$ Geographically speaking, the imperial connections went even further. Fascist ecologist, Jorian Jenks, and Richard Reynell Bellamy, author of the 'authorized' history of the BUF, had both been farmers in New Zealand. ${ }^{84}$ For these individuals, their conception of whiteness, as well as of non-white people, had been forged in the crucible of the colonies. And so, when it came to imperial issues like the future of India, the BUF regurgitated almost unreconstructed the hierarchies of colonial racism.

The BUF's commentary on India shows the extent to which they imbibed the doctrines of colonial racism. The terminology of martial race theory, an idea which emerged out of the aftermath of the 1857 Indian Mutiny, was regularly employed in fascist periodicals. ${ }^{85} \mathrm{~A}$ feature of both popular and official discourse during the late nineteenth century, it functioned as a way of

\footnotetext{
81 Schwarz, The White Man's World, 20-21.

82 W. F. Mandle, 'The leadership of the British Union of Fascists,' The Australian Journal of Politics and History 12, no. 3 (1966): 364.

83 Mandle, 'The leadership of the British Union of Fascists,' 364, 365. For more on GordonCanning's colonial connections, see Graham Macklin, 'Fascist Jihad: Captain Robert Gordon-Canning, British Fascist Antisemitism and Islam,' Holocaust Studies 15, no. 1-2 (2009): 78-100.

84 Mandle, 'The leadership of the British Union of Fascists,' 365, 369.

85 Heather Streets, Martial Races: The Military, Race and Masculinity in British Imperial Culture, 1857-1914 (Manchester; New York: Manchester University Press, 2004), 11, 18.
} 
simultaneously denigrating the masculinity, and claims to self-determination, of the Indian critics of the Raj. The theory ranked the various ethnic groups of the Indian subcontinent into a 'descending scale' of colonial masculinity according to the number of characteristics they shared with the 'manly Englishman'. ${ }^{86}$ By the late nineteenth century, in response to the rise of India's Nationalist movement, the figure of the Westernised Indian intellectual was placed at the bottom of this hierarchy. The mainstay of the fledgling Nationalist movement, this group was regarded as a horrid hybrid of Indian racial inferiority and Western intellectual effeteness, and referred to as babus. ${ }^{87}$

The BUF saw a betrayal of Empire in every concession made to India. Chesterton was greatly offended that, in his view, Britain was surrendering India to 'Parsee moneylenders and Babu politicians, who would faint if a squib burst at their feet'. 88 Joyce denounced the Indian Nationalist movement as a 'fake movement' bankrolled by 'the big baboo millionaires of Bombay and Calcutta' and run by a parasitic 'swarm of lawyers, money-lenders and half-baked students'. ${ }^{89}$ Mosley called on the British government to stand fast before these lesser men and refrain from 'backing out of India, jabbering and salaaming before the frowns of a few Babu lawyers. ${ }^{90}$

Reviewing the autobiography of prominent Indian nationalist politician, Jawaharlal Nehru, in Action, John Beckett illustrated how completely the BUF had absorbed imperialist racial doctrines. He commented that 'the educated Indian ... has usually lost the manliness of his more Asiatic brothers and acquired a superficial Western cunning. ${ }^{91}$ Just as these racist views had long been used to legitimize British colonial rule, British fascists used them to support their case for imposing fascist leadership on India. The Empire, they argued, required a steady, strong and masculine hand; Indian men, supposedly afflicted with 'native hysteria', were simply not masculine enough to govern themselves. ${ }^{92}$

India stood as an example, for the BUF, of the problem with democracy in general. Just as in Europe, they argued, it had catapulted to the forefront a class of effeminate 'talkers', rather than a small band of manly 'doers'. They believed

86 Mrinalini Sinha, Colonial Masculinity: The 'Manly Englishman' and the 'Effeminate Bengali' in the Late Nineteenth Century (Manchester; New York: Manchester University Press, 1995), 2.

87 Sinha, Colonial Masculinity, 2.

88 Chesterton, 'Empah" Day,' 9.

89 'Lucifer', 'A Betrayal of the Nation,' Blackshirt, 9 (June 16, 1933), 1, 4.

9o Lang, 'Albert Hall Rally,' 2.

91 John Beckett, 'An Imperial Tragedy,' Action, 23 (July 23, 1936), 12.

92 Beckett, 'Imperial Tragedy,' 12. 
that executive rule by 'great men' had built the Empire in the first place and that the 'political blundering and weakness' they associated with democracy was losing it. ${ }^{93}$ The solution, both at home and abroad, was a return to government by 'a ruler who knows his mind and gets his way'. ${ }^{94}$ In other words, the BUF looked forward to a fascist autocrat, governing in the spirit of imperial heroes like Clive and Hastings.

The Italian invasion of Abyssinia in October 1935 was an occasion for a perfect fusion of the BUF's staunch imperialism, racism, and their fascism. While Mussolini had been funding the BUF since 1933, its defence of the invasion was not simply a hollow political manoeuvre; suppressing the Abyssinians was regarded as a pro-British, pro-Empire struggle. ${ }^{95}$ They defended the invasion as a modern equivalent of British imperial heroism. Raven Thomson compared it to the reconquering of the Sudan in the 189 os by Kitchener, then Commanderin-Chief of British forces in Egypt, 'Like the Italians, [Kitchener] was marching against a barbaric enemy with a reputation for bravery and military skill. ${ }^{96}$ For Raven Thomson, Kitchener and Mussolini were doing the same thing, simply 'put[ting] down slavery and barbarism with a strong hand'. 97

Mosley likened it to another event from the 'greater days' of British imperialism, an 1868 expedition in Abyssinia led by army officer Robert Napier whose mission it was to rescue several captive missionaries and two representatives of the British government. ${ }^{98}$ In Napier's four hundred mile march across Abyssinia, his killing of five hundred Abyssinians and wounding of one thousand five hundred more, Mosley saw a feat of imperial heroism. It was, for him, a shining example of how the British built their Empire and 'taught the barbarous tribes of Africa that British subjects cannot be molested with impunity'. ${ }^{99}$ Mussolini was only acting in the tradition of those Empire builders, argued Mosley, when he made it clear that 'he would not stand for the same thing'.100 Robert Gordon-Canning, who wrote on foreign affairs for BUF periodicals, found the Italians guilty of 'no more than ... a task so often carried out by our country and to the glory of our countrymen - carrying the reign of peace to

\footnotetext{
93 Chesterton, 'Empire Day,' 6.

94 'Lictor', 'India and the Future,' Fascist Quarterly 1, no. 4 (1935), 450-451.

95 Thurlow, Fascism in Britain, 106-108, 146; Claudia Baldoli, Exporting Fascism: Italian Fascists and Britain's Italians in the 1930s (Oxford; New York: Berg, 2003), 101.

96 Alexander Raven Thomson, 'With Kitchener to Khartoum,' Action, 2 (February 28, 1936), 3.

97 Raven Thomson, 'With Kitchener to Khartoum,' 3.

98 “Blood Follows Oil” : Fascism Alone Challenges Internationalism,' Blackshirt, 124 (September 6, 1935), 2.

99 'Blood Follows Oil", 2.

100 'Blood Follows Oil”,' 2.
} 
warring tribes and bringing to these backward and barbaric races the science of the West.'101

Coursing through the BUF's response to the invasion was an indignation at the violence used by the Abyssinians in self-defence. In British fascist accounts, this violence was racialized and portrayed as unforgivably black; the Abyssinians were not soldiers repelling an invasion but 'Black Murderers'.102 The Italians had to win, not simply for the sake of Italy but for the sake of the white race. Spectres of Britain's colonial past, images of literal and figurative castration and of the violation of white women, were invoked to drive home the point that this was not simply a foreign skirmish but a high stakes battle over the future of white rule in Africa. Failure to subdue the Abyssinians, cautioned one BUF writer, would mean that British subjects in nearby Kenya would 'pay the price' with 'the plunder of their cattle, the enslavement of their women, and the death or shameful mutilation of their own persons.' ${ }^{103}$

Chesterton reiterated similar threats when the exiled Emperor of Abyssinia, Haile Selassie, visited Britain in June 1936. Enraged that a white woman had greeted Selassie by curtsying, Chesterton expressed his hopes that the footage would not be shown out in Britain's colonies where 'the "Black Peril" to womanhood ... is sufficiently menacing without being encouraged in this disgraceful fashion. ${ }^{104}$ Here, again, is an example of the influence colonial experience had on the BUF's fascism. Born to British settlers in South Africa six months before the outbreak of the Boer War, Chesterton grew up amid a number of 'major' scares over 'the Black Peril', a phrase used to refer to a sudden spate of sexual assaults against white women allegedly perpetrated by black men. ${ }^{105}$ Gareth Cornwell has noted that these panics did not correspond to actual incidences of rape, reflecting instead flashpoints of racism, sexual jealousy and misogyny on the part of white South African men. ${ }^{106} \mathrm{He}$ adds that the 'Black Peril' was an integral and constantly reoccurring feature of white ethnic identity in South Africa and, in the years after the Boer War, functioned as an racial 'rallying point' for English and Afrikaners. ${ }^{107}$

\footnotetext{
101 Robert Gordon-Canning, 'The Abyssinian Rout,' Action, 3 (March 6, 1936), 13.

102 E. D. Hart, 'The Bleating Wolf of Ethiopia: Britain's Press Pets,' Action, 11 (April 30, 1936), 7.

103 Hart, 'The Bleating Wolf,' 7.

104 A.K. Chesterton, 'Mr. Tafari in Town,' Blackshirt, 136 (June 20, 1936), 3.

105 University of Bath Library: A.K. Chesterton Papers, B.3-B.7, unpublished Ms of Chesterton's autobiography Blame Not My Lute, chapter 2, f. 13.

106 Gareth Cornwell, 'George Webb Hardy's The Black Peril and the social meaning of "Black Peril" in early Twentieth-Century South Africa,' Journal of Southern African Studies 22, no. 3 (1996): 441-445, 448-450.

107 Cornwell, 'Black Peril,' 441.
} 
Like Chesterton and others, William Joyce coloured the conflict as a clash between the triumphant progress of white civilisation and its subjugation by the Oriental and African barbarian.'108 Picking up where imperialism left off, Joyce believed that fascism was fighting in the corner of 'white civilization' against 'Negroes, Hindus, Japs, and Jewish razor-men'. ${ }^{109}$ Marilyn Lake and Henry Reynolds have pointed to the turn of the twentieth century as a key moment in the international ascent of politicized whiteness. This was illustrated for them by the rise of a collective white identity out of a transnational racial discourse between the United Kingdom, the United States, and selfstyled 'white man's countries' like Australia and South Africa. British fascism spoke in the same language, of 'whiteness in defensive, but defiant, mode' against a dreaded rising tide of 'colour'.110

Much like the turn of the century white supremacism in Lake and Reynolds' work, British fascism was motivated by anxious premonitions of the loss of imperial power. Combining fanatical antisemitism with imperialist racism, Joyce declared that European fascists were locked in a chaotic battle with 'Jewish international finance and Jewish-controlled Bolshevism', twin forces attempting to mobilize 'the coloured races against the white."111 In adopting fascism, wrote Joyce, Germany and Italy had already answered the call to fight for white survival and Britain must do so next. The coming fascist revolution, like the suppression of Abyssinia, was regarded as one part of the greater fulfilment of the white man's imperial 'Destiny'.112

This racially conscious fascist imperialism underpinned the BUF's peace campaign. Launched in 1935 in support of the Italian invasion of Abyssinia, under the slogan 'Mind Britain's Business', the BUF revived the campaign on numerous occasions in the latter half of the decade in the face of growing hostilities in Europe. Their constant refrain was that Britain should concentrate on its own affairs, chiefly the development of the Empire, and not concern itself with what other nations were doing. Joyce foresaw a 'new Imperialism' in which the fascist Empires of Britain, Germany and Italy would ensure peace

108 William Joyce, 'The Forces of Darkness Arrayed against Fascism,' Blackshirt, 119 (August 2, 1935), 2.

109 Joyce, 'Forces of Darkness,' 2.

110 Marilyn Lake \& Henry Reynolds, Drawing the Global Colour Line: White Men's Countries and the International Challenge of Racial Equality (Cambridge: Cambridge University Press, 2008), 3 .

111 William Joyce, 'Collective Security', Fascist Quarterly 1, no. 4 (1935), 429.

112 Joyce, 'Forces of Darkness,' 2. 
through mutual agreements over access to raw materials and markets for goods, thus avoiding 'another civil war of the white race.'113

In their hoped-for fascist future, the BUF wanted to replace the League of Nations, which they hated, with '[t]he real League of Nations' that 'would come from universal Fascism. .114 The League's policy of collective security was presented as further evidence of a plot by the 'sub-men' to 'surrender white civilization to the Orient'. ${ }^{\prime 15}$ Instead, the Empire would form the basis of what Mosley dubbed 'The Immense Majesty of Fascist Peace', guaranteeing 'peace over at least a quarter of the earth's surface.'116 World peace was conceived of as a matter of imperial strength; 'peace in China, Abyssinia, or India' would not come without 'a power strong enough to enforce it'.117

In the context of this campaign, the frontiersman became a symbol of a fascist peace. As a movement containing many veterans of the First World War, including Mosley and Chesterton, the soldier did often feature in BUF propaganda, though as a victim, robbed either of his life, his health or the promise of a 'land fit for heroes'. The 'Empire Builder', on the other hand, represented the height of Britain's constructive triumph. He could stand for many of the virtues of the soldier while avoiding the associated destructiveness of world war and replacing it with the 'constructive' aspirations of Empire building. Thus BUF members were encouraged to look to 'the great pioneer work of soldiers acting as administrators' across the British Empire and their 'heroic' efforts 'in tackling the problems of peace.'118 Jorian Jenks advised his fellow BUF members to champion the diligent heroism of Britain's imperial pioneers and solitary colonial officials who tamed wild lands and kept 'backward' populations in order. ${ }^{119}$

It is worth noting here that the BUF's construction of imperial pioneers for 'peace' had a very different emphasis from the Nazi's use of Britain's imperial legacy. This different emphasis highlights one of the key differences between British and German fascism; while the Nazis were obsessed with expansion, the BUF were interested in imperial consolidation and peace of a very specific, fascist kind. The Nazis admired the brutality of British imperialism, the

113 William Joyce, 'Fascist Peace,' Action, 49 (January 23, 1937), 6.

114 'Mosley's Great Peace Speeches: "Not One Drop of British Blood Shall Be Spent Except in Defence of Britain",' Blackshirt, 124 (September 6, 1935), 2.

115 Joyce, 'Collective Security', 422.

116 Oswald Mosley, 'The Immense Majesty of Fascist Peace,' Fascist Week, 8 (December 29, 1933-4 January, 1934), 5; Joyce, 'Collective Security', 430.

117 Joyce, 'Collective Security', 429.

118 Roger Gould, 'Crown and Empire,' Action, 66 (May 22, 1937), 3.

119 Jorian Jenks, 'Empire Union or Foreign Intrigue?' Action, 170 (May 27, 1939), 7. 
inclination and ability of men like Drake, Raleigh, Nelson and others in overseas domination. ${ }^{120}$ In the early days of the Third Reich, an array of books on the British imperial heroes was published. ${ }^{121}$ A great many of these were, in a quite calculated way, targeted at young readers and school pupils.

While the Nazis desired to win an Empire through war, the BUF believed that only through peace would Britain be able to hold onto and develop its Empire. The choice before Britain, according to Jenks, was between 'an anti-Axis policy in Europe' and thus war or peace with 'a strong and United Empire.'.22 The BUF emphatically chose the latter. Imperialism was a central part of the fascist case for peace and they continued their push for a fascist peace even into the early years of the Second World War. This ultimately led a British government nervous of potential fifth columnists to intern Mosley and other leading members on 23 May, 1940, and outlaw the organisation altogether on 10 July, 1940.

\section{Conclusion}

Shut out of mainstream politics during the interwar period, a certain masculinist strain of imperialism found political expression in British fascism. Drawing deeply on the imperial discourse of the mid-to-late nineteenth century and the right-wing radicalism of the Edwardian period, the British Union of Fascists built their ideology out of the past and present of the British Empire, and conceived of their hoped-for future in its image. For their new fascist man, they drew on imperial constructions of the 'White Man' as a symbol of the mythic power to re-make the world through will alone.

The mission of earlier imperialists, like Kipling and Baden-Powell, had been to secure imperial greatness using the values of colonial masculinity to transform the metropole. For Mosley and his recruits, the same means were the route to a fascist British Empire. Old imperial, racist stereotypes became a means for the BUF to simultaneously deny people of colour in India and Africa the right to self-determination and to support their foreign fascist comrades. Finally, Mosley and his recruits regarded the renewal of the British Empire, led by fascist frontiersmen and supported by fellow fascist Empires in Germany and Italy, as the key to world peace. In the end it was the BUF's enthusiasm for

120 Gerwin Strobl, The Germanic Isle: Nazi Perceptions of Britain (Cambridge: Cambridge University Press, 2000), 75-76.

121 Strobl, The Germanic Isle, 77.

122 Jenks, 'Empire Union or Foreign Intrigue?' 7. 
this kind of fascist internationalism that provoked the government to intern its leading members and outlaw the organisation.

British fascism was a marginal political force. The BUF failed to win power and in terms of membership, peaked at around 40,000 to 50,000 in 1934, never to recover these numbers again. ${ }^{123}$ However, it must not be written off as a negligible political anomaly in the history of interwar Britain or of interwar British imperialism. The fact that the BUF so frequently enlisted the history of the British Empire in its political struggle, that it so often made use of ideological leftovers of the British imperialism, and that it was able to fit its white supremacist fascism so easily into the framework of imperial racism, demand that British fascism be incorporated into the broader historiographical debate about the effect the Empire had on British politics and society.

The imperialism espoused by the BUF was rooted in ideas that, decades before 1930s, were regarded as mainstream, and the imperialist ideologues they venerated were far from fringe enthusiasts. To take just a few of their imperial idols as examples: Kipling was a widely loved poet and Baden-Powell, already a heroic veteran of the Boer War, had his status as a national figure cemented with the popularity of his Scout Movement. That the BUF lauded these figures, despite the fact that none of them could be accurately described as fascists, does not mean that they were simply seeking to validate fascism by association but points to some real ideological affinities. In this light, the political failure of British fascism, and the associated failure of marginalized Conservative Party diehards, illustrates the changing nature of British imperialism and of masculine constructions of the national character during the interwar period. Looked at in this way, British fascism appears as a stain (albeit a small one) left on Britain's political fabric by an earlier and, by the 1930s, out-of-step version of imperialism.

123 G. C. Webber, 'Patterns of Membership and Support for the British Union of Fascists,' Journal of Contemporary History 19, no. 4 (1984): 595 